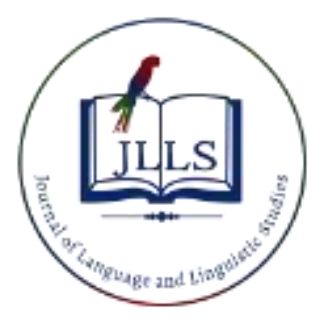

Available online at www.jlls.org

JOURNAL OF LANGUAGE AND LINGUISTIC STUDIES

ISSN: 1305-578X

Journal of Language and Linguistic Studies, 16(1), 42-58; 2020

\title{
Longitudinal effects of second language on first language narrative skills and executive functions of preschool children
}

\author{
Asli Aktan-Erciyes \\ ${ }^{a}$ Kadir Has University, Cibali Mahallesi, Kadir Has Cad. No:17 Fatih / ISTANBUL, 34083

\section{APA Citation:}

Aktan-Erciyes, A., (2020). Longitudinal effects of second language on first language narrative skills and executive functions of preschool children., Journal of Language and Linguistic Studies, 16(1), 42-58. Doi: 10.17263/jlls.712638

Submission Date:02/09/2020

Acceptance Date:03/09/2020

\begin{abstract}
The present study investigated the longitudinal effects of early exposure to L2-English on L1-Turkish language competence, narrative skills and executive functioning. We asked whether early immersion-like exposure to L2, starting around 3 years of age, would have reflections on L1 competence, L1 narrative skills and gains in cognitive flexibility. Thirty 4-year-olds attending two types of preschools participated in the study: L1-preschools $(\mathrm{N}=12)$ with Turkish instruction and L2-preschools $(\mathrm{N}=18)$ where children were exposed only to English $(6 \mathrm{hrs})$ throughout the day. Children were initially tested at time 1 (T1) at age 4 and at time 2 (T2), a year later when they were 5. At T1, results revealed that children attending L2-preschools displayed no differences in executive functions performance compared to children in L1-preschools. Likewise, there were no differences for L1 competence as well as L1 narrative skills. At T2, however, for L1 narrative skills, children attending L1-preschools displayed significantly higher performance compared to peers in L2-preschools. For executive functioning again there were no differences between the participants. The differences in narrative competence at $\mathrm{T} 2$ might indicate that children in L2-preschools lack sufficient input in story telling in L1 to support narrative competence. For future consideration how literacy acquisition would interact with the effects of L2 exposure should also be investigated.
\end{abstract}

(C) 2020 JLLS and the Authors - Published by JLLS.

Keywords: Turkish; English; narrative skills; executive functions; L2 acquisition

\section{Introduction}

There are a growing number of Turkish-English bilingual preschools and full-time English preschools in urban contexts in Turkey. This development necessitates the examination of possible effects of early exposure to a second language before the first language has been fully acquired in contexts where bilingualism is not the natural condition of the home. The positive effects -- such as those on executive functioning and metalinguistic awareness -- are to be well received but the possible negative effects need also be considered as they may cause delay of full-fledged native competence.

\footnotetext{
${ }^{1}$ Corresponding author. Tel.: +90 (212) 5336532

E-mail address: asli.erciyes@khas.edu.tr
} 
Today's trends towards multilingualism force upper middle-class families to show extensive interest in second language teaching for their preschool aged children. An investigation of the level of the first language (L1) competence under different levels of exposure to the L2 is expected to shed light on whether these conditions may be conducive to delay in the L1 development as well as demonstrating the possible advantages of acquiring a second language at a young age.

\subsection{Literature review}

\subsubsection{Second language acquisition and bilingualism}

Second language acquisition (SLA) is the process by which people learn a second language in addition to their mother tongue. A well accepted definition of bilingualism in the field is it is a phenomenon where an individual has competence at a certain level in both of his/her languages (Bialystok, 2001).

Two kinds of bilingualism are distinguished on the basis of the timing of the acquisition of the two languages. In case of simultaneous bilingualism, the child is exposed to two languages from birth onwards. Successive or sequential bilingualism, on the other hand, is defined as the situation where L2 is learned after L1 is fully acquired (Kohnert, Bates \& Hernandez,1999).

Individuals become bilingual or multilingual for different reasons that have implications for the status of their L1 and L2. First, there are "elite bilinguals" which refers to individuals whose dominant language is the majority language, but they choose to become bilingual either because they live abroad or travel around the world or for some other reason but not to serve their basic needs in the community (Skutnabb-Kangas, 1981). These individuals belong to upper-middle class, and their children attend schools where the language medium is not their mother tongue. Second, there are "children from linguistic majorities"; children going to French schools in Canada present a good example for this group. The third group is "children from bilingual families". They are the ones who have parents with different mother tongues. Last is the category formed by "children from linguistic minorities". These children, typically those of immigrant groups, are the ones who are mostly at risk due to the fact that their native language is not valued as much as the other one (Skutnabb-Kangas, 1981).

\subsubsection{Relationship between the two languages in bilingualism and significance of narrative skills}

In order to investigate the effects of one language on the other, one has to understand the relationship of L1 and L2. There have been various attempts to explain how the two languages are represented in a bilingual mind by models of acquisition. Cook (2003) has proposed that L2 users differ from monolinguals in their usage and knowledge of both L1 and L2. He considers several models before coming to the conclusion that "L2 users have different minds from those of monolinguals" (Cook, 2003, p.5). The "separation model" proposes that the two languages constitute separate systems. In this model, there is no point in discussing the effects of L2 on L1 since it is assumed that there are separate systems for storing and processing the two languages. The opposite possibility is the "integration model" where the L2 user is assumed to have a unitary language system for L1 and L2 with a single mental lexicon rather than two separate lexicons for each language (Cook, 2003). Bialystok (1998) arrives at a similar conclusion regarding the nature of the bilingual mind noting that these models are too simplistic and that a continuum of intermediate possibilities between separation and integration is the most convenient model. As one piece of evidence among others "for the complex structure that weaves two languages and a meaning system", she reports results from studies of how Spanish-English bilingual children learn two vocabularies in the early stages of language acquisition (Pearson, Fernandez, Lewedeg \& Oller 1993; Pearson \& Fernandez 1994). She underlines the high amount of individual variability among children in terms of the rate and level of learning, the balance between their two languages, and their learning environments, as indicators of the complexity of this relationship. 
Genesee, Nicoladis \& Paradis (1995) argue that there is an early differentiation of the two languages if exposure to L2 starts before 5 years of age. Genesee et al. examined language differentiation of five bilingual children between the ages of $1 ; 10$ and $2 ; 2$ by observing them with each parent separately and together on different occasions. The results indicate that although these children displayed code mixing, they were obviously able to differentiate between both of the languages. The researchers argue that codemixing instances could not be a sign of the existence of a single structure for both languages at stages as early as 1 year of age, and claim that children do have an early differentiation in their minds pertaining to the languages they are exposed to. Meisel (1989) suggests that this differentiation might occur as early as 2 years of age if the child acquires both languages simultaneously.

The acquisition order of the two languages, whether simultaneous or sequential, has a bearing on the relationship between the two languages. Findings from studies of simultaneous acquisition or 'multiple first language' acquisition (De Houwer, 1995; Meisel, 2004) can be summarized as follows: grammatical development in the two languages is differentiated early, development proceeds through the same sequences as in monolingual acquisition but not at a same rate, and as a result grammatical knowledge in each language is no different than that of a monolingual (Meisel, 2007).

In sequential bilingualism, however, acquisition may result in partial success in terms of grammatical development when one of the languages of a bilingual is the weaker (i.e., the child talks less in) and the other the stronger language. In such cases, children's acquisition of the L2 is argued to resemble adult L2 acquisition rather than multiple L1 acquisition (Meisel, 2007). Some properties of the weaker language include "(1) omission of obligatory elements, (2) problems with inflectional morphology, and (3) deviant word order patterns" (Meisel, 2007, p.500).

L1 and L2 acquisition differ in many ways in different stages of attainment. For example, in the initial stage of L2 acquisition, L2 utterances are longer compared to L1 utterances in L1 acquisition (Meisel, 2007). When the course of acquisition is compared, L1 happens really fast but the rate of L2 development is slower. There is greater variability across learners of L2 while there is not much variation for L1. As for ultimate attainment, only few L2 learners can reach native-like competence. (Meisel, 2007; White \& Genesee, 1996). On the other hand, Ioup, Boustagui, Tigi \& Moselle (1994) investigated Julie- an adult who has gained native-like proficiency in Eyptian Arabic in a natural learning setting. The analyses of extensive test results of Julie showed that an adult can achieve native-like proficiency of L2 in an 'untutored setting'. Long, (2000) indicates that adults and adolescents can learn L2 grammar incidentally and that focusing on meaning is sufficient to achieve full-native like competence.

Narrative development is another important milestone for language development. By age 4, children are assumed to have acquired the basic grammar of their language, have a well-developed vocabulary and to be able to produce coherent sentences (Hoff, 2003). However, their ability to produce connected discourse is as yet not fully developed. Their linguistic competence in L1 will therefore be better reflected in more sophisticated tasks which require them to produce chunks of discourse longer than a sentence, as in accounts of a day or personal and fictional narratives. Narratives involve relatively extended pieces of discourse where the information to be communicated needs to be organized in a coherent way in accordance with a theme. Narrative production requires the ability to sequence events in a temporally and causally related way towards the achievement of a goal, also providing information about the motives and reactions of the actors that bring about those events (Berman \& Slobin, 1994). In telling short picture elicited stories, while 3-year-olds give picture descriptions, 4-year-olds relate events temporally and 5-year olds start to relate events as episodes of a theme (Aksu-Koç, 2005). A narrative task to assess children's L1 competence should therefore be able to tap variability in children's developing competence in language use and shed light upon possible effects of L2 exposure on L1. 


\subsubsection{Cognitive consequences of second language acquisition}

Bilingualism is often associated with benefits in cognitive functioning. An important domain is that of executive functioning where bilingual children and adults are found to have an advantage over monolinguals (Bialystok, 2001; Bialystok \& Martin, 2004).

Executive functioning has been found to be related to the development of numerous abilities children possess such as attentional skills, knowledge and usage of rules, and theory of mind (Zelazo, Reznick and Frye, 1997). In Zelazo et al.'s (1997, p.219) problem-solving frame work, executive function is said to involve "representing a problem flexibly, planning organized sequences, executing those sequences and evaluating the results of one's rule use." It is stated that within the age range of 2 to 5 , there are dramatic changes in all four aspects of executive function stated above. Children gradually mature as they develop their abilities in representations, planning, execution and evaluation. Among the specific components of executive functioning, inhibition is one of the most widely studied construct. (Zelazo et al, 1997)

Nearly all of the research that indicates a cognitive advantage for second language learners focuses on bilinguals. Bilinguals are found to be at an advantage when the task at hand requires shifting (also called the cognitive flexibility), updating (also called the working memory) and inhibition (Bialystok \& Viswanathan, 2009; Bialystok, 2009). Inhibitory control has been documented to have a central role in cognitive tasks when young children are considered. It is defined as "suppressing a prepotent behavioral option as well as initiating and maintaining a subdominant option" (Kochanska et al. 2000 p.220; Bialystok \& Martin, 2004). These processes are regarded as milestones of executive functioning (Miyake, Friedman, Emerson, Witzki \& Howerter, 2000). Miyake et al. (2000) postulated differences in "mental set shifting (shifting), information updating and monitoring (updating) and inhibition of prepotent responses (inhibition)." Confirmatory factor analysis has revealed that these three functions are clearly separable under the main heading of executive functions. Findings that reveal contradictory results about bilingual advantage in executive functions should be evaluated in terms of the cognitive processes involved in the tasks used in assessment (Bialystok, Craik, Klein and Viswanathan, 2004). The tasks that have misleading perceptual information are accomplished better by bilinguals, however the ones that are based on analytical knowledge without misleading information are performed equally well by monolinguals and bilinguals. Research indicates that bilinguals have advantage over monolinguals in conflict resolution where the children have to rely on their ability to solve problems based on conflicting rules which can be seen as a component of executive control (Bialystok, 1999).

In the theory of cognitive complexity and control (CCC), Zelazo and Frye (1998) argue that preschool children lack the necessary representation and executive functioning that is required to solve problems which have conflicting rules. According to the theory there are differences between control and representational processes. Control processes involve selective attention where the individual has to attend to required aspects of a problem and at the same time inhibit misleading information. This further allows them to switch between competing alternative routes. On the other hand, representational processes involve understanding the perceptual information, accessing the related knowledge and make necessary inferences. In other words, control processes involve regulating the information when there are conflicting cues, whereas no conflict is resident when representational processes are considered. Zelazo and Frye (1998) showed that most of the 3 year olds in DCCS (Dimensional Card Change Sort task) task, which requires both inhibition and switching, perseverate due to this lack of cognitive control. They argue that this ability begins to emerge around age 4. Bilinguals are argued to be outperforming monolinguals on tasks that involve control processes but do equally well on representational ones (Bialystok \& Martin, 2004).

No one can deny that a bilingual's representation of the world is different than that of a monolingual. Constant need to encode and interpret the words from two languages under the same concepts enables 
bilinguals to have more advanced representation of the world and yet a richer one (Bialystok and Martin, 2004). Bialystok (2007) proposes that regardless of whether the bilinguals' two languages are represented in a shared system or in a distinct one, bilinguals have different representational structures for language than monolinguals. The difference lies in the fact that bilinguals can confine themselves to a single language system while having the representations of the two linguistic systems active in mind at the same time.

There is evidence that for bilinguals, the two representational systems are both active even when only one language is in use (van Heuven, Dijkstra \& Grainger 1998). Rapid and efficient switching between representations is crucial for a fluency in both languages. A bilingual person decides which of the two systems to activate whenever needed (Bialystok et al. 2004). Green's (1998) model of Inhibitory Control suggests that there is a mechanism that controls the joint functioning of the two languages. Whichever language is active, the bilingual person has to inhibit the other one and keep on with the one that is active. In order to have fluent expression there should be constant exertion of that inhibition. Therefore, bilinguals have an advantage compared to monolinguals and this advantage remains as long as the bilingual conditions do not alter. Bialystok and Martin (2004) compared bilinguals and monolinguals on the 'switching' component of executive functions, using the DCCS and found that the ability to switch between dimensions while inhibiting the active one is an aspect of executive functioning. This ability was more developed in bilinguals than in monolinguals (Bialystok \& Martin 2004; Bialystok, 2009).

Another model proposed to explain inhibitory control is the Bilingual Interactive Activation Model. In this model, representations of the words of both languages are organized in a hierarchical fashion and compete for selection when needed (van Heuven, Dijkstra \& Grainger 1998). The model proposes that a bilingual goes through a competition between and within a language which is determined by lateral inhibition where representations are hierarchically organized. It is proposed that there are adjacent representations (of two languages for the same concept) which inhibit each other; therefore, selection of a response decreases the probability of the adjacent response to be selected. The model is an account of semantic processing that bilinguals go through in everyday life. Bialystok et al. (2005) argue that in Bilingual Interactive Activation Model, the properties of the stimulus are the key to determine the inhibition whereas in Inhibitory Control Model, inhibition is much more a central component which controls a bilingual's processing.

The DCCS (Zelazo, Frye and Rapus,1996) is a task which is widely used in the assessment of executive functions. On this task, children are required to sort the given card according to a given dimension. The dimension changes during the task which requires the child to both switch between dimensions and inhibit the previous dimension. For example, children are given sets of cards which have circles and triangles in two different colors. If first (pre-switch phase) sorting criteria is color, the child sorts out the cards into two sets according to the color, then the child is asked to sort the cards according to shape (post-switch phase- dimensional change). The ability to switch between dimensions while inhibiting the active one is an aspect of executive functioning. Bialystok (1999) investigated whether bilinguals possess an advantage in inhibitory control in this non-verbal task, DCCS. She proposed that analysis is necessary to understand the sorting rule in the first phase (pre-switch phase) and control is necessary to ignore the previous rule and not perseverate in the second phase (post-switch phase). Sixty children participated in the study and ages ranged from $3 ; 2$ to $4 ; 9$ for the younger group and from 5;0 to 6;3 for the older group. Half of the participants were English monolinguals and other half was ChineseEnglish bilinguals. They were all tested on PPVT-R, Visually-Cued Recall Task, Moving Word Task and DCCS. The results of the research showed that monolinguals and bilinguals had similar vocabulary development and also similar capacity for working memory. However, in DCCS which required conflicting rules to be inhibited, bilinguals outperformed monolinguals. These results not only reveal 
the ability of bilingual children to control attention more than the monolinguals but also that representing structures and controlling them are discrete functions (Bialystok, 1999).

Whether the bilingual advantage on inhibitory control continues to be prevalent throughout the life span is an important issue and has also been investigated. Bialystok et al. (2004) propose that if the advantages associated with executive functioning in bilinguals continue in adulthood, it might also act as a protective mechanism for adults against decreased cognitive functioning due to aging. Aging is associated with decline in quality of attentional control, but not in representational knowledge. In their study, younger and older adults (mean age 42 and 70 respectively) were assigned to monolingual and bilingual groups and tested on both verbal and executive functioning tasks. The Simon task was used to test for the assumed bilingual advantage associated with inhibitory control. The Simon task is widely used to reveal the effect of stimulus-response compatibility on performance. It is used to assess attentional abilities and inhibitory control associated with bilingualism. A target stimulus (which has both position and response information) is presented in different locations of the computer screen together with a set of rules. To give an example, either blue or a brown box appeared on either left side, right side or at the center of the screen. The subjects were required to press a certain key either on left or right side of the keyboard (i.e. for brown box they pressed left shift key marked " $X$ ", for blue box they pressed right shift key marked "O"). The location where the boxes appear is sometimes contradicted with the location of the key (incongruent trials), requiring the subjects to ignore the location of the box and attend to color only. On some trials, the location of the key subjects had to press were in line with the box position (congruent trials). The increase in response time (RT) for incongruent trials compared to congruent ones is called the "Simon Effect". The explanation of the effect is the stimulus-response incompatibility because of response-selection processes. The task requires both to allocate the attention selectively on the stimulus at the same time ignoring the misleading cues. The results of the study showed that monolinguals and bilinguals differed in their performance in Simon Task. Bilinguals (both younger and older age group) responded faster for both congruent and incongruent trials and they exhibited a smaller Simon effect. The results also showed that the age related increase in Simon effect was reduced for bilingual adults. As expected, bilinguals outperformed monolinguals for incongruent trials but there was also an advantage for bilinguals in terms of RT for congruent trials. The results of the task gave insight about life-long advantages of bilingualism and encouraged the investigation of the "Simon Effect" in bilingual children which is later studied by Bialystok and Viswanathan (2009) with a special task called the "Faces Task" that will further be discussed in detail.

Bilingual advantages on cognitive processing do not encompass all aspects of executive functioning. In order to differentiate the advantages, Carlson and Meltzoff (2008) carried out a comprehensive study which included executive function tasks for children. Nine executive functioning tasks, which loaded on two factors which are 'conflict' and 'delay' were applied to three groups of children: 1) native bilinguals, 2) monolinguals (English), and 3) English speakers -of low SES families- enrolled in secondlanguage immersion kindergarten. The results showed that bilinguals had an advantage for 'conflict' tasks over the monolingual and the immersion group. The difference found for bilinguals in the conflict subscale was not seen in delay tasks. On the other hand, the results of the Expressive one-word Picture Vocabulary Test -showed an advantage of monolinguals over bilinguals.

Further and deeper analyses for the inhibition component came from Bialystok and Viswanathan (2009). They investigated three components of executive functioning: response suppression, inhibitory control and cognitive flexibility in order to isolate the components of executive functioning and test the previous findings of advantages associated with bilingualism. In the study, inhibition of an interfering cue was defined as" interference suppression" and inhibition of a habitual response was labeled as "response inhibition". Another aim of the study was to compare bilinguals of different cultures to determine the generality of the differences. For this purpose, ninety 8 -year-old children took part in the 
study. There were three groups of children (1) Monolinguals in Canada (2) Bilinguals in Canada and (3) Bilinguals in India. A special task called the "faces task" was used. Each trial of the task displayed a face on a computer screen with either green or red eye, and the eyes looked either left, right or straight. In the task, children in front of a computer screen, responded to the trials by pressing the button either on the same side of the box containing the asterix (if the eyes on the face were green) or on the other side of the box containing the asterix (if the eyes on the face was red). The eyes looked either to correct side of the button, incorrect side of the button or straight. There were two types of trials blocked or mixed. In blocked, all trials had either green or red eyes. In mixed trials they were mixed (one red eye preceding a green eye) so the order was mixed. Bilinguals performed better at trials which required inhibitory control (eyes looking in opposite direction to the correct box) and switching (mixed design trials i.e. different eye colors in single block) but not at response suppression (straight eye condition). There were differences between monolinguals and bilinguals in favor of bilinguals on trials that required inhibitory control and cognitive flexibility but there were no differences for response suppression. The results show that contrary to earlier findings (Bialystok, 2001), bilinguals do not outperform monolinguals simply in inhibitory control but also in cognitive flexibility which underlies task switching. These results support the distinction between the two processes; inhibitory control and cognitive complexity that are studied under the term 'inhibition' in both adult (Miyake et al. 2000) and child (Zelazo \& Frye, 1998) literature.

A study by Poulin-Dubois, Blaye, Coutya \& Bialystok (2011) investigated whether the advantages bilingual children possess on tasks measuring executive functioning could also be observed as early as 24 months of age. A battery of executive functioning tasks including three conflict tasks: Multilocation (where child is expected to find a treat hidden in a set of drawers in her presence by the researcher at the same time inhibiting the wrong cues given verbally), Shape Stroop (a task where in stroop condition children had to respond by pointing the designated fruit embedded in different larger fruits), Reverse Categorization (where the child is habituated to put small blocks in small bucket and large blocks in large bucket, after switching, the rule was reversed i.e. small blocks in large bucket) and two delay tasks: Gift Delay and Snack delay was administered. A total of 75 children were tested all at age around 24 months and half of them being English-French bilinguals and half of them were English monolinguals. Parents were given questionnaires (MB-Communicative Development Inventory) for vocabulary measures of their children. As expected, monolinguals were found to be ahead of bilinguals in vocabulary development. Bilingual children did not differ from monolinguals on delay tasks; however, they were significantly better on Stroop task, a task which required children to make a novel response while inhibiting the prepotent one.

In summary, previous research points to positive effects of bilingualism on executive functions but the findings regarding the effects of L2 on L1 appear equivocal as they are dependent on a number of factors among which are, age of onset, conditions of exposure, level of proficiency achieved, status of the two languages, and SES characteristics of the family.

\subsubsection{Present study}

Present study aims to investigate effects of second language exposure on first language competence as reflected in narratives as well as vocabulary and executive functions in early childhood. For this purpose, we conducted two studies, in Study 1 we tested 4-year-old preschool children and in Study 2 we tested same children after a year when they were 5 . The context of acquisition of second language is a well-resourced one and both of the languages, Turkish and English are highly valued. The specific hypotheses are as follows: 
(1) Four-year-old children who attend L1-Turkish preschools will perform better in L1 competence as measured by a standardized Turkish Language test (TEDIL) compared to their peers in L2-English preschools. This difference will prevail after one year when they are 5 years old.

(2) On executive functioning tasks, 4-year-old children who attend L2-preschools will perform better than peers who attend L1-preschools as a consequence of bilingual advantage. Again, this difference will remain the same after one year when they are 5 .

(3) Four-year-old children who attend L1-Turkish preschools will perform better in L1 narrative skills task compared to their peers in L2-English preschools. This difference will remain the same after one year when they are 5 .

\subsection{Research questions}

We asked two research questions:

(1) Does learning a second language early in childhood has an effect on children L1 competence as reflected in language competence tests as well as narrative skills and executive functions concurrently and longitudinally?

(2) Does learning a second language early in childhood has an effect on executive functioning skills concurrently and longitudinally?

\section{Method - Study 1}

\subsection{Participants}

Thirty 4-year-old children attending two types of preschools participated in the study: L1-preschools $\left(\mathrm{N}=12, \mathrm{M}_{\mathrm{age}}=55\right.$ months $\left.\mathrm{SD}=4.16\right)$ with Turkish instruction and L2-preschools $\left(\mathrm{N}=18, \mathrm{M}_{\mathrm{age}}=54\right.$ months $\mathrm{SD}=3.52$ ) where children are exposed only to English throughout the day. Children of the present study who attended L2-English preschools are regarded as bilinguals as their level of L2 as measured by Peabody Picture Vocabulary Test-4 (PPVT-4) indicates that they are not different than their Englishspeaking monolingual peers.

All children were from L1: Turkish families, having native Turkish-speaking mothers and fathers. Both 4-year-old children who attend L2-preschools have attended these preschools for two school years (testings were always held owards the end of second semester). All families were of middle-to-high socio-economic standing with similar mother's level of education.

\subsection{Instruments}

\subsubsection{Language Competence Tasks}

Türkçe Erken Dil Gelişimi Testi (TEDIL): We used TEDİL (Topbaş \& Güven, 2011) as an indication of receptive and expressive language competence. This instrument is an adaptation to Turkish of the English assessment instrument TELD-3 (Hresko, Reid \& Hammill, 1999). The test is used to assess receptive and expressive language of children between $2 ; 0$ to $7 ; 11$ years of age. For the standardization study, 1171 typically developing monolingual children, 73 monolingual language impaired, 20 mentally retarded and 4 children with autism spectrum disorder have been tested. Seven different regions of Turkey were selected to form the normative sample (Topbaş \& Güven, 2011). The test consists of a total of 86 questions; 37 questions in the receptive subtest and 39 questions in the expressive subtest. Children were tested starting from their age-equivalent questions with visually presented cards. 
The receptive subtest included questions for the following categories: Postpositions, quantifiers, relative clauses, word-order, temporal relations, ordinal expressions, metalinguistic skills, complex vocabulary, semantic relations, grammatical awareness, conceptual relations, word meanings, syntactic knowledge, abstract words, synonyms and complex instructions, Expressive subtest included questions for the designated categories: Plurals, noun inflections, superordinate categories, logical inference, picture description, derivational suffixes, subject-verb agreement, imitation of sentences, short narrative production and sentence completion.

Test of Early Language Development - 3 (TELD-3): TELD-3 (Hresko et al. 1999) was administered to children who attend L2-English preschools to assess the children's level of L2. The TELD-3 was standardized on 2,217 children representing 35 states. This is a norm referenced instrument for measuring both receptive and expressive language in English.

\subsubsection{Narrative skills tasks}

A wordless picture story (The Horse-Bunny story, Nicolopoulou, 2009) was used. Children were shown 4-pictures in sequence of a full story where a bunny is seen resting in the field and eating carrots. The next picture depicts a horse who comes and steals the carrot basket from the bunny. In the third picture the bunny runs after the horse to have her carrots back. In the fourth picture they share the carrots. Children's narratives were videotaped and later transcribed.

\subsubsection{Executive functioning tasks}

Dimensional change card sorting task (DCCS): DCCS (Zelazo, Frye and Rapus 1996) was administered in order to assess children's inhibition and switching abilities. The task requires children to sort a series of test cards. Two target cards (blue rabbit and red boat) and six test cards (three red rabbits and three blue boats) were used. Target cards were attached to two separate boxes as labels and stayed there throughout the whole session. In the pre-switch phase children were asked to sort the cards either by color or by shape and put the cards to the correct box face down in order to prevent influencing the next trials. In the post-switch trials children were asked to sort the cards according to the other dimension. Order of dimensions used in pre- and post-switch sessions were counterbalanced across children. Each child was given two demonstration trials before testing trials. Number of correct postswitch trials were taken as a proxy for accuracy performance.

\subsection{Data collection procedures}

All children were tested close to the end of the school year so that there were two school years of L2 immersion for 4-year-old children who attend to L2-preschools. All children were tested in the school setting in a quiet room. Sessions were performed by the researcher in the designated order: (1) Narrative skills task (2) Executive Functioning tasks and (3) TEDİL. Children who attended L2 English preschools were also given TELD-3 as a control task for their L2 competence.

\subsection{Data coding and analyses}

\subsubsection{Data coding}

Narrative structure coding: The stories were analyzed for narrative structure following the story grammar proposed by Stein and Glenn (1979), for narrative quality and for linguistic form. A 'Narrative Structure Score' was based on the presence of the major plot components in the story, presented in Table 1, with definitions and an example from a child's story. The narrative structure score was the sum of all components listed above (ranging from 0 to 7 in total with a score of 0 or 1 for each item according to their presence/absence). If there are more than one utterance for each component it is considered as 1 and counted only once. (i.e. "a horse" and "a bunny" is counted 1 for character presence). All narratives 
were coded by two independent raters. There was a high agreement between the raters for narrative structure scores for Time $1(\kappa=.87(95 \% \mathrm{CI}, .82$ to .94$), p<.01)$ as well as Time $2(\kappa=.95(95 \% \mathrm{CI}$, .92 to .97$), p<.01)$.

Linguistic Complexity Coding: The stories were anayzed based on the properties of clauses they have. A clause was defined as a predicate and its related arguments which was taken as the unit of analysis. The total number of clauses, and total number of complex clauses were calculated. All narratives were coded by two independent raters. There was a high agreement between the raters for linguistic complexity scores for both Time $1(\kappa=.90(95 \% \mathrm{CI}, .88$ to .95$), \mathrm{p}<.01$ and Time $2(\kappa=.91(95 \% \mathrm{CI}$, .88 to .94$), p<.01)$.

Types of clauses considered for linguistic complexity were as follows:

1. Simple Clauses: A single predicate used to convey meaning.

2. Complex Clauses:

a) Infinitival Clauses: A clause with two predicates joined by the -mak construction.

"Koşmak istedi”, "yemeye başlamış". 'wanted to run', 'started to eat'

b) ulticlause utterance - Coordinate: Two single clauses joined with a coordinating conjunction" such as and, but, and then, as well as with sequenced verbs such as "yatmış havuç yiyor".

c) Multiclause utterance - Subordinate: Two single clauses joined by a subordinate conjunction such as -diği zaman 'when', çünkü 'because', -dığı için 'for that reason' -dıktan sonra 'after', 'while', 'so'.

d) Multiclause utterance-Subordination with converbs: Two single clauses joined as V+ken (koşarken) 'while running', V+ince (koşunca)'when ran', V+ip (koşup 'running'), V+erek (koşarak)'by means of running', $\mathrm{V}+\mathrm{a} \ldots \mathrm{V}+\mathrm{a}$ (koşa koşa) 'in the manner of running 'etc.

Linguistic Complexity score is defined as the percentage of complex clauses with respect to total number of clauses.

\subsubsection{Data analyses}

In order to compare children attending to L1 and L2-preschools, independent-samples t-test analyses were carried out. School type was the independent variable. Dependent variables were T1-TEDIL receptive and expressive scores, DCCS score, horse-bunny story narrative structure score and horsebunny story linguistic complexity score. All mean and standard variation values of the scores can be seen in Table 1. We calculated standard TELD-3 English scores for children attending L2-preschools for Time 1 and Time 2. The average standard scores were $93.65(\mathrm{SD}=7.6)$ and 102.71 (SD=12.43) for Time 1 and Time 2, respectively. A score of 100 corresponded to 50th percentile which showed that children attending L2-preschools were qualified to be bilinguals. 
Table 1. Means and standard deviations of Time1 and Time 2 scores

\begin{tabular}{lrrrrrrrr} 
& \multicolumn{4}{c}{ Time 1 } & \multicolumn{3}{c}{ Time 2 } \\
\cline { 2 - 9 } & \multicolumn{2}{c}{ English preschool } & \multicolumn{2}{c}{ Turkish preschool } & \multicolumn{2}{c}{ English preschool } & \multicolumn{2}{c}{ Turkish preschool } \\
& Mean & Std. & Mean & Std. & Mean & Std. & Mean & Std. \\
\hline TEDİL-Receptive & 27.33 & 3.51 & 31.83 & 3.29 & 28.83 & 4.80 & 31.67 & 2.15 \\
TEDİL-Expressive & 28.61 & 3.63 & 32.50 & 1.86 & 29.67 & 4.42 & 33.67 & 2.15 \\
Narrative structure & 3.22 & 1.59 & 4.13 & 1.59 & 3.50 & 1.38 & 5.90 & 0.99 \\
DCCS & 5.11 & 1.64 & 9.39 & 2.00 & 3.92 & 2.27 & 8.42 & 1.98 \\
Linguistic complexity & $33.61 \%$ & 0.32 & $23.16 \%$ & 0.17 & $42.52 \%$ & 0.32 & $47.43 \%$ & 0.25 \\
\hline
\end{tabular}

\section{Results -Study 1}

3.1. Comparison of children who attend to L1 and L2-preschools for Turkish receptive and expressive skills, DCCS, narrative structure and linguistic complexity at Time 1.

We conducted independent samples t-tests taking school type as a grouping variable and all other scores as dependent variables. The results of the t-tests showed that there were no differences between the two groups of children in neither of the scores. All t-test statistics can be seen in Table 2:

The results indicate that there was no significant difference in neither of the variables including cognitive, language and narrative competence between children attending to L1-Turkish and L2-English scores. However, horse-bunny story has yielded short narratives from children which made it difficult to highlight any differences between the two groups.

Table 2. t-test statistics of Time 1 analyses

\begin{tabular}{lrrr} 
& t-value & \multicolumn{1}{c}{$d f$} & \multicolumn{1}{c}{${ }^{*}$} \\
\hline T1-TEDİL-Receptive & -0.99 & 28 & 0.33 \\
T1-TEDİL-Expressive & -0.72 & 28 & 0.48 \\
T1-Narrative structure & 1.67 & 28 & 0.11 \\
T1-DCCS & -0.49 & 28 & 0.63 \\
T1-Linguistic complexity & -0.74 & 28 & 0.47 \\
\hline * significance is 2-tailed & & &
\end{tabular}

\section{Method - Study 2}

\subsection{Participants}

Same thirty 4-year-old children who attended Study 1 participated one year after Study 1. Again, they were attending two types of preschools: $\mathrm{L} 1$-preschools $\left(\mathrm{N}=12, \mathrm{M}_{\mathrm{age}}=69\right.$ months $\left.\mathrm{SD}=4.06\right)$ and L2preschools $\left(\mathrm{N}=18, \mathrm{M}_{\mathrm{age}}=68\right.$ months $\left.\mathrm{SD}=3.25\right)$ All children were from L1: Turkish families, having native Turkish-speaking mothers and fathers.

\subsection{Instruments}

\subsubsection{Language Competence Tasks}

We again used TEDIL receptive and expressive subtests to assess L1 language competence and TELD-3 for English competence for children attending L2-English schools. 


\subsubsection{Narrative skills tasks}

In Time 2, we used a more complex story book that would elicit more differences between the two groups. A wordless picture story book named Frog, where are you? (Mayer, 1969) was used. Children were instructed to elicit narratives depending on the story that is depicted in the book. They were first given a chance to have a look at the book from start to the end, then within the second inspection they formed their stories. Children's narratives were videotaped and later transcribed for coding purposes.

\subsubsection{Executive functioning task}

Dimensional change card sorting task (DCCS) - border version: A more difficult version of the DCCS (Zelazo, Frye and Rapus 1996) was administered. This version consists of 12 trials. Six cards have border and remaining six do not. On each trial, rules are repeated ("If there's a border, play the color game. If there's no border, play the shape game"). As in the standard version, experimenter responds to children in a neutral, non-evaluative, non-corrective fashion.

\subsection{Data collection procedures}

All children were again tested close to the end of the school year so that there were three school years of L2 immersion. All children were tested in the designated order: (1) Narrative skills task (2) Executive Functioning task and (3) TEDİL. Again children attending L2-English preschools were administered TELD-3 for control purposes for L2 competence.

\section{Results - Study 2}

5.1. Comparison of children who attend to L1 and L2-preschools for Turkish receptive and expressive skills, DCCS, narrative structure and linguistic complexity at Time 2.

We conducted independent samples t-tests in order to compare children attending to L1 vs. L2preschools. For TEDILL receptive and expressive scores and DCCS-border, there was again no difference between the two groups. However, for Narrative structure score for frog story, children attending L1preschools $(\mathrm{M}=5.90, \mathrm{SD}=.99)$ performed better that their peers in L2-preschools $(\mathrm{M}=4.12, \mathrm{SD}=1.59)$, $t(28)=3.15, \mathrm{p}=.004$. For linguistic complexity again there was advantage in terms of children attending L1-preschools $(\mathrm{M}=.47, \mathrm{SD}=.24)$ compared to children in L2-preschools $(\mathrm{M}=.23, \mathrm{SD}=.17), t(28)=3.21$, $\mathrm{p}=.003$. All t-test statistics can be found in Table 3 .

The results of Time 2 measures yielded advantages pertaining to children who attend L1-preschool, compared to L2-preschools. The fact that the differences were found both narrative structure as well as linguistic complexity point to an important aspect of bilingual education.

However, there were again no differences in L1 receptive and expressive skills. This might be due to the fact that Turkish is the dominant societal language which served as a protective factor for children attending L2 preschools.

Table 3. t-test statistics of Time 2 analyses

\begin{tabular}{lrrr} 
& $t$-value & $d f$ & \multicolumn{1}{l}{$p$} \\
\hline T2-TEDIL-Receptive & 0.15 & 28 & 0.88 \\
T2-TEDIL-Expressive & -1.59 & 28 & 0.12 \\
T2-DCCS & 1.31 & 28 & 0.20 \\
T2-Narrative structure & -3.16 & 28 & 0.004 \\
T2-Linguistic complexity & -3.20 & 28 & 0.003 \\
\hline * significance is 2-tailed & & &
\end{tabular}




\section{Discussion}

The present study aimed to answer two major research questions: (1) Does learning a second language early in childhood has an effect on children L1 competence as reflected in language competence tests as well as narrative skills and executive functions concurrently and longitudinally? and (2) Does learning a second language early in childhood has an effect on executive functioning skills concurrently and longitudinally? For this purpose, we tested preschool children who attend to L1preschools vs. L2-preschools when they were 4 and 5 years of age in a longitudinal design.

We hypothesized that children who attend to L1-preschools will outperform their peers in L1 competence as measured by TEDIL in both receptive and expressive subtests. However, findings revealed that children have similar competence level both when they were 4 years old as well as when they were 5. This may be due to the fact that L1 Turkish is the dominant societal language therefore immersion like L2 instruction at preschool might not be reflected on vocabulary. This finding is in line with the literature where similar second language practices are held, such as (Burger, Weinberg, Hall, Movassat and Hope, 2011), Finland (Björklund and Mard-Miettinen, 2011, L1: French), Ireland (Duibhir, 2011, L1: Irish) and Hong Kong (Hoare, 2011, L1: Cantonese) where L2 immersion schooling does not result in adverse effects on L1. The effects of learning a second language in the preschool years with an immersion curriculum when the first language is not yet fully stable, has been investigated more often for the children of disadvantaged populations than for the children of higher socioeconomic standing. The results of these studies have indicated negative consequences for L1 in contexts where it is the non-dominant (minority) language (Fillmore, 1991; Cummins, 2001; Ventureyra, Pallier \& Yoo, 2004). Literature that shows disadvantage of bilingual children in vocabulary compared to monolinguals come from societies where L1 is not the dominant language in the society and the exposure to L1 is further restricted in daily life. However, present study investigates the phenomenon from an advantageous population where children are from high SES backgrounds.

On executive functioning tasks we used DCCS which is a good indicator of cognitive flexibility. Cognitive flexibility is found to be more advanced due to acquisition of more than one language. However, there was no difference between the children who attend to L1 vs. L2-preschools. Children of the present study were 4 years old when they were first tested and they were 5 in Study 2 . The age of the children are young and executive functioning skills are still being developed at a great pace at those ages. Moreover, those children who attend to L2-preschools may not be qualified as bilinguals, therefore did not show the positive effects. Cummins (1976) suggests in his Threshold hypothesis that it is only possible to experience cognitive advantages of L2 acquisition when development of L1 and L2 proceeds in balanced development. Therefore, children who attend L2 schools in the present study might not be balanced bilinguals to possess these advantages.

Our last hypothesis was that children who attend to L1-preschools will perform better in L1 narrative skills reflected in narrative structure as well as linguistic complexity. Although such differences were not found in Study 1 when children were 4 years of age, there was a significant difference in favor of children who attend L1-preschools when children were 5 years old. There might be two reasons of this finding. First of all, in Study 1 horse-bunny story was used and it as simple story with only 4 pictures. Therefore, the story might have fallen short to depict probable differences between the two groups. When children were 5 years old, they were asked to tell Frog story which is a depiction of more complicated sequence of events compared to horse-bunny story. Another reason of lack of difference at 4 years of age might be due to fact that narrative abilities are late to emerge and develop at 4 years of age. Therefore, children attending to difference language practices might not be seen at that age.

Future studies might also involve investigating children after they acquire literacy which is one of the most influential factors that aids narrative development. 


\section{Conclusions}

Although acquiring a second language is often associated with cognitive gains and positive outcomes, there might be some aspects of language that should be supported in first language. Especially early in development when L1 grammar has not fully been established, it is of special importance that both L1 and L2 are supported in a balanced manner.

\section{Ethics Committee Approval}

The author confirms that ethical approval was obtained from Kadir Has University (Approval Date: 14/03/2016).

\section{Acknowledgements:}

We thank all the families and institutions who made this research possible

\section{References}

Aksu-Koç, A. (2005). Role of the home-context in the relations between narrative abilities and literacy practices. In D. Ravid \& H. Bat-Zeev Shyldkrot (Eds.), Perspectives on language and language development (pp. 257-274). Dordrecht, the Netherlands: Kluwer.

Berman, R., \& Slobin, D. I. (1994). Relating events in narrative: A crosslinguistic developmental study. Hillsdale, NJ: Lawrence Erlbaum Associates

Bialystok, E. (1998). Beyond binary options: Effects of two languages on the bilingual mind. http://www.thefreelibrary.com/Beyond+binary+options\%3a+effects+of+two+languages+on+t he+bilingual+mind.-a093027774.

Bialystok, E. (2001). Bilingualism in development: Language, Literacy and Cognition. Cambridge University Press: Cambridge.

Bialystok, E., \& Martin, M. (2004). Attention and inhibition in bilingual children: evidence from the dimensional change card sorting task. Developmental Science, 7, 325-339.

Bialystok, E., Craik, F.I.M., Grady, C., Chau, W., Ishii, R., Gunji, A., Pantev, C. (2005). Effect of bilingualism on cognitive control in the Simon task: evidence from MEG. Neuroimage, 24, 4049.

Bialystok, E. \& Viswanathan, M. (2009). Components of executive control with advantages for bilingual children in two cultures. Cognition, 112, 494-500.

Bialystok, E. (2009). Bilingualism: The good, the bad, and the indifferent. Bilingualism: Language and Cognition, 12(1), 3-11.

Björklund, S., \& Mård-Miettinen, K. (2011). Integrating multiple languages in immersion: Swedish immersion in Finland. In Tedick, D. J., Christian, D., \& Fortune, T. W. (Eds.). Immersion education: Practices, policies, possibilities (Vol. 83). (pp. 13-35). Bristol, UK: Multilingual Matters.

Carlson, S. M., \& Meltzoff, A. N. (2008). Bilingual experience and executive functioning in young children. Developmental Science, 11, 282-298.

Cook, V. (2003). Effects of second language on first. Great Britain: Cronwell Press Ltd.

Cummins, J. (2001): "Bilingual children's mother tongue: Why is it important for education." Sprogforum, 19, 15-20. 
De Houwer, A. (1995). Bilingual language acquisition. In (Eds.) Fletcher, P. \& MacWhinner, B. Handbook of child language. London, UK: Basil Blackwell.

Duibhir, Ó. P. (2011).'I thought that we had good Irish': Irish immersion students' insights into their target language use. In Tedick, D. J., Christian, D., \& Fortune, T. W. (Eds.). Immersion education: Practices, policies, possibilities (Vol. 83). (pp 145-165). Bristol, UK: Multilingual Matters.

Fillmore, L. W. (1991). When learning a second language means losing the first. Early childhood research quarterly, 6(3), 323-346.

Genesee, F., Nicoladis, N. \& Paradis, J. (1995). Language differentiation in early bilingual development. Journal of Child Language, 22, 611-631.

Green, D. W. (1998). Mental control of the bilingual lexico-semantic system. Bilingualism: Language and Cognition, 1, 67-81.

Hoare, P. (2011). Context and constraints: Immersion in Hong Kong and mainland China. Immersion education. Practices, policies, possibilities. (pp. 211-230), Ontario, Canada: Multilingual Matters.

Hoff, E. (2003). The specificity of environmental influence: Ses affects early vocabulary development via maternal speech. Child Development, 74(5), 1368-1378.

Ioup, G., Boustagui, E., El Tigi, M., \& Moselle, M. (1994). Reexamining the critical period hypothesis: A case study of successful adult SLA in a naturalistic environment. Studies in Second Language Acquisition, 16, 73-98

Kochanska, G., Murray, K., \& Harlan, E. T. (2000). Effortful control in early childhood: Continuity and change, antecedents, and implications for social development. Developmental Psychology, 36, 220-232

Kohnert, K. J, \& Bates, E. (1999). Balancing bilinguals: Lexical-semantic production and cognitive processing in children learning Spanish and English. Journal of Speech Language and Hearing Research, 42, 1400-1413.

Long, M. (2000). Focus on form in task-based language teaching. In R. D. Lambert \& E. Shohamy (Eds.), Language policy and pedagogy: Essays in honor of A. Ronald Walton (pp. 179-192). Philadelphia, USA: Benjamins.

Meisel, J. (1989). Early differentiation of languages in bilingual children. In Hyltenstam, K. \& Obler (Eds.), Bilingualism across the lifespan. (pp. 43-62) Cambridge, UK: Cambridge University Press.

Meisel, J. M. (2004). The bilingual child. In T. K. Bhatia \& W. C. Ritchie (Eds.), The handbook of bilingualism (pp. 91-113). Blackwell Amsterdam: Benjamins.

Meisel, J.M. (2007). The weaker language in early child bilingualism: Acquiring a first language as a second language?, Applied Psycholinguistics, 28, 495-514.

Miyake, A., Friedman, N. P., Emerson, M. J., Witzki, A.H. \& Howertet, A. (2000). The unity and diversity of executive functions and their contributions to complex 'frontal lobe' tasks: a latent variable analysis. Cognitive Psychology. 41, 49-100.

Nicolopoulou, A. (2009). The horse and bunny story. Picture sequence stories to be used in the development of MB-CDI III.

Pearson, B.Z., Fernandez, S.C., Lewedeg, V., Oller, D.K. (1993). The relation of input factors to lexical learning by bilingual infants, Applied Psycholinguistics, 18(1), 41-58.

Pearson, B. Z. (2009). Children with two languages. In E. Bavin (Ed.), Handbook of child language. Cambridge: Cambridge University Press.

Poulin-Dubois, D., Blaye, A., Coutya, J., \& Bialystok, E. (2011). The effects of bilingualism on toddlers' executive functioning. Journal of Experimental Child Psychology, 108, 567-579.

Skutnabb-Kangas, T. (1981). Bilingualism or not: The education of minorities. Clevedon, England: 


\title{
Multilingual Matters.
}

Stein, N. \& Glenn, C. (1979). An analysis of story comprehension in elementary school children. In R. D. Freedle (Ed.), Advances in discourse processes: Vol. 2. New directions in discourse processing (pp. 53-119). Norwood, NJ: Albex.

Topbaş, S., Güven, S. (2011), Türkçe Erken Dil Gelişimi Testi (TEDILL), Ankara: Detay Yayıncılık.

van Heuven, W.J.B., Dijkstra, T. and Grainger, J. (1998) Orthographic neighborhood effects in bilingual word production. Journal of Memory and Language 39, 458-483.

Ventureyra, V. A., Pallier, C., \& Yoo, H. Y. (2004). The loss of first language phonetic perception in adopted Koreans. Journal of Neurolinguistics, 17(1), 79-91.

White, L. \& Genesee, F. (1996) How native is near-native? The issue of ultimate attainment in adult second language acquisition. Second Language Research, 12, 233-265.

Zelazo, P.D., Carter A, Reznick J.S., Frye, D. (1997). Early development of executive function: A problem-solving framework. Review of General Psychology, 1, 1-29.

Zelazo, P., \& Frye, D. (1998). Cognitive complexity and control: The development of executive function in childhood. Current Directions in Psychological Science, 7, 121-125.

\section{İkinci dil ediniminin okul öncesi dönemde anlatı becerileri ve yönetici işlevlere}

\author{
olan boylamsal etkisi
}

\begin{abstract}
$\ddot{\mathbf{O z}}$
Bu çalışma çocukların erken dönemde ikinci dilde bir yuvaya devam eden çocuklarla anadilde yuvaya devam eden çocukları Türkçe dil gelişimi, anlatı becerileri gelişimi ve yönetici işlevler açısından boylamsal olarak karşılaştırılmasını hedeflemektedir. Bu amaçla, otuz 4 yaşında çocuk araştırmaya katılmıştır. Bu çocukların 12'si 3 yaşından itibaren Türkçe yuvlara devam etmekte, 18'i ise 3 yaşından beri İngilizce eğitim verilen yuvalara devam etmektedir. Katılımcılar iki ayrı zaman diliminde (4 yaşında ve 5 yaşındayken) iki çalışmaya katılmışlardır. Birinci çalışmada tüm çocuklara anadil becerilerini sınamak amacıyla TEDİL testinin alıcı ve ifade edici dil alt testleri uygulanmış, tavşan-at resimli hikayesinin anlatımı istenmiş ve Değişken Kriterli Kart Eşleme Testi (DKKE) uygulanmıştır. Birinci çalışmada iki grup arasında hiçbir testte fark bulunamamıştır. Bir yıl sonra yapılan ikinci çalışmada TEDİL ve DKKE uygulamalarında fark bulunmazken anlatı becerilerinde anlamlı farklar bulunmuştur. İkinci çalışmada tavşan-at hikayesinden daha farklı bir hikaye olan Kurbağa, Neredesin? isimli yazısız kitap kullanılmıştır. Anlatı becerilerinin değerlendirilmesi için anlatı kurgusu puanlanmış, kullanılan dilin yapısı dilbilimsel olarak incelenmiştir. Sonuçlar Türkçe yuvalara devam eden çocukların 5 yaşında İngilizce yuvalara devam eden çocuklardan kurgusal olarak daha yetkin hikayeler oluşturduklarını göstermiş ayrıca kullanılan dilbilimsel yapılardaki karmaşıklık yüzdesinin de daha yüksek olduğu bulunmuştur. Sonuçlar boylamsal olarak ikinci dilde yuvaya gitmenin anadildeki bazı alanları olumsuz etkileyebileceğini göstermiştir. Anlatı becerilerindeki yetkinliğin dildeki gelişmişlik düzeyi öngörmede standart ölçüm araçlarından daha uygun olabileceği de görülmüştür.
\end{abstract}

Anahtar sözcükler: İkinci dil edinimi, okul öncesi, anlatı becerileri, yönetici işlevler, Türkçe, İngilizce

\section{AUTHOR BIODATA}

Aslı Aktan-Erciyes is an Assistant Professor of Psychology at Kadir Has University, Istanbul. She received her $\mathrm{PhD}$ in Developmental Psychology from Boğaziçi University, İstanbul under supervision of Prof. Ayhan AksuKoç and Prof. Ali İ. Tekcan. She received her MA in Developmental Psychology again from Boğaziçi University. 
Dr. Aktan-Erciyes is interested in language and cognition interactions, and she uses bilingualism as a tool to study this interaction. One line of her research investigates how early and intense exposure to second language affects first language and vice versa. She is also interested in narrative development and event conceptualization. She follows a developmental perspective in her research and try to integrate converging evidence from multi-level sources. 